\title{
Silencing and Silence: Language and Specialized Listening in a Long- Term Institution for the Elderly
}

\author{
By Simone Maximo Pelis \& Nirvana Ferraz Santos Sampaio
}

UESB (State University of Southwest Bahia)

Abstract- This article presents the result of research developed with the language of elderly residents at the Long Term Care Facility for the Elderly - ILPI, in Vitória da Conquista, Bahia, Brazil. In response to the initial questions as to whether institutionalization affects the language of the elderly, whether the resignification of verbal by non-verbal speech occurs, and whether silence, as language is part of an alternative system of possible meaning for the elderly, it was perceived that language in institutionalized long-lived individuals it reveals that in response to diversified processes of silencing, they have instituted silence as a possibility of reframing, and structuring of meaning. We collected data through the filming and recording of the elderly in enunciative-discursive situations, considering the uniqueness of each subject's history and their respective crossings as well as the condition of production of the narratives based on the concept of data-finding by Maria Hadler Coudry (1), aligned with notions relevant to Linguistics in the theoretical-methodological perspective of Discursive Neurolinguistics.

Keywords: language; silence; old man; long-term institution.

GJHSS-G Classification: FOR Code: 200399

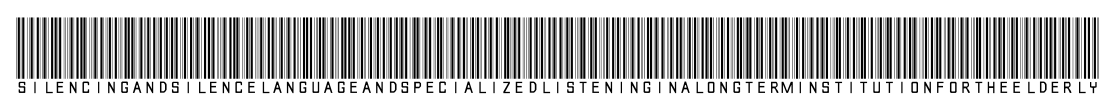

Strictly as per the compliance and regulations of:

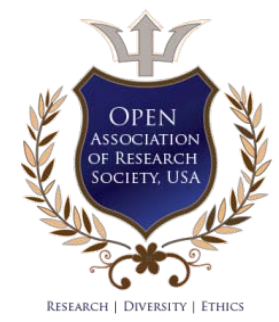

(c) 2020. Simone Maximo Pelis \& Nirvana Ferraz Santos Sampaio. This is a research/review paper, distributed under the terms of the Creative Commons Attribution-Noncommercial 3.0 Unported License http://creativecommons.org/licenses/by-nc/3.0/), permitting all non-commercial use, distribution, and reproduction in any medium, provided the original work is properly cited. 


\title{
Silencing and Silence: Language and Specialized Listening in a Long-Term Institution for the Elderly
}

\author{
Simone Maximo Pelis ${ }^{\alpha} \&$ Nirvana Ferraz Santos Sampaio ${ }^{\circ}$
}

Abstract-This article presents the result of research developed with the language of elderly residents at the Long Term Care Facility for the Elderly - ILPI, in Vitória da Conquista, Bahia, Brazil. In response to the initial questions as to whether institutionalization affects the language of the elderly, whether the re-signification of verbal by non-verbal speech occurs, and whether silence, as language is part of an alternative system of possible meaning for the elderly, it was perceived that language in institutionalized long-lived individuals it reveals that in response to diversified processes of silencing, they have instituted silence as a possibility of reframing, and structuring of meaning. We collected data through the filming and recording of the elderly in enunciative-discursive situations, considering the uniqueness of each subject's history and their respective crossings as well as the condition of production of the narratives based on the concept of datafinding by Maria Hadler Coudry (1), aligned with notions relevant to Linguistics in the theoretical-methodological perspective of Discursive Neurolinguistics. The work presents a major finding regarding silence as a language anchored in multidisciplinary concepts (of Music, Philosophy, Psychoanalysis, Discourse Analysis, and Linguistics) relevant to this work that deals with the value of silence: it is not zero, emptiness, which leads us to interpret it as meaning. Thus, the silence, permeating each sign, expands and gives meaning, it becomes the possible resource for the institutionalized subject (re) to elaborate desires and responses.

Keywords: language; silence; old man; long-term institution.

\section{InTRODUCTION}

T his text discusses the language on aging, which is a dynamic, uninterrupted process that occurs from conception, segmented into several complex stages during the vital cycle of the human being, based on research developed with five institutionalized elderly in an institution of lengthy stay for the elderly, located in Vitória da Conquista, Bahia, Brazil, Abrigo Nosso Lar, parallel to this group, we carried out activities with three other older adults living in their homes. However, for this article, data on four elders were used. The motivating questions of the research were: Does institutionalization affect the vernacular of the elderly? Does the resignification of verbal speech occur by non-verbal language? Is silence, as a language, part of an

Author a: Psychologist, Specialist in Geriatrics and Gerontology, Master in Linguistics - PPGL in - UESB. e-mail: Simone.maximo@gmail.com Author o: Professor, PhD in Linguistics - PPGL in - UESB).

e-mail:nirvanafs@terra.com.br alternative system of possible meaning for these older adults?

Thus, aging, social silencing, institutionalization, silence, and the impacts of this institutionalization and silencing on the life of the elderly were guiding themes for understanding silence as a possibility of reframing and structuring meaning. However, specialized listening leads to this reframing, amid enunciative-discursive situations, as can be seen in the following sections.

\section{il. From Aging to Social Silencing, to Institutionalization: The Silence}

It is common knowledge that the world population is aging due to several factors, including the advance of medicine, the improvement of quality of life, and reduction of the global birth rate in proportion to the mortality rate, thus leading to a growth in longevity. In Brazil, the Brazilian Institute of Geography and Statistics (2), in data presented in 2014, demonstrates that the exponential increase in life expectancy will lead to a population of older adults over 60 years of age, higher than the population of young people and adults up to 26 years old, in 2050. Aging can occur in a natural or pathological context (when physiological impairments take place). Whatever the circumstances, aging causes biological, cognitive, socioeconomic changes that impact the lives of long-lived individuals. In Western culture, these changes result in the deprivation of the individual's social value by not producing any more (labor and financial losses); and in several cases as a result of family abandonment, social exclusion, the institutionalization of the long-living individual occurs.

Despite dating from 1890 the first institution to shelter the elderly (Asylum São Luiz, in Rio de Janeiro), studies by Berger (3) report that in Brazil, the act of institutionalizing old age, dated from the beginning of the 20th century, more precisely the from the 1930s and began with the Church's welfare activities, through nursing homes, retirement homes or shelters. At this time, beggars, abandoned children, mentally ill, prostitutes, older adults: they all lived in one place, however, with the growing demand for the institutionalization of the elderly, in 1964, the Santa Casa de Misericórdia de São Paulo acquired the profile of a house specifically gerontology, in Vitória da Conquista, 
Bahia, in 1954 the AbrigoNosso Lar had its inauguration, providing shelter and housing orphaned, retired and sick children. In 1983, the institution started to serve exclusively older adults. This historical reality of the longterm institution in Brazil supports and proves that the relationship between the institutionalization of the longliving individual and "the loss of autonomy, functional losses, fragmentation of family relationships, fragmentation of social identity and the deterioration of the identity of the long-living individual" (4) is causal.

Once institutionalized, the elderly lose much of their uniqueness. With the lack of social interaction with the others and with the world and the reduction of stimuli, they lead to the impoverishment of knowledge of the world, which depletes the dialogue and, consequently, the language of the elderly. Since it is a social fact, language's existence is based on the need for communication (5), the impoverishment of communication and interaction changes the individual's perception of the world and himself. The loss of autonomy, not doing social actions destitutes the importance of being, making the saying inaudible, and as the social discourse of a supporting character censors the identity of the elderly individual divided by the losses, it prints indignant conformity to silence. This relationship of censorship, the said, the unsaid and the power to say, characterizes the process of silencing. It is possible to comprehend the dynamics of silencing and the politics of silence by contextualizing the relationship between what is said and what is not said with the power to say (6).

\section{a) Institutionalization, Silencing, and Language}

When institutionalized, the long-lived individual delivers his belongings to the institution, as the space to store them, in most cases, is limited to a wardrobe.
Also, it is common to observe the belongings of an older adult with another in the institutions, even when identification occurs. It is a feeling of not belonging, of not being or having anything that is yours. Not being anyone, not being home. The feeling of not belonging is another form of silence resulting from the collective common to the institutions' norms, as mentioned by ROCHA (7). The institution works for the collective, so it is not possible to individualize the service, therefore, when "everything belongs to everyone and for everyone"; it consequently cancels "mine" (4).

What is the relationship that silencing has to language? Silence is the continuous process of preventing speech. To say something is to state. To enunciate is to put the language into operation. Language and speech are languages. They play a social role, and the act of speaking begins in the environment, so individual awareness is a socioecological fact (5). Therefore, anchored in the assumptions of Discursive Neurolinguistics, we can affirm that each individual expresses his integrality and the different factors that produce it (social, cultural, and historical) through language (8). This is the relevance of apprehending the subjectivities of institutionalized older adults, textualizing their narratives enunciated verbally, non-verbally, or semiotically. The materialization of these narratives and discourse is the recognition that the physically confined older adult is led to imprisoning themselves. They are silenced.

\section{b) Silencing, Silence, and implications for the lives of institutionalized elderly}

Silencing, a process that occurs continuously, has silence as its final product. We have elaborated the table below presenting some of the many forms of silencing. Let's see:

Table 1: Types of Silencing

\begin{tabular}{|c|c|c|}
\hline Type & Descrimination & Example \\
\hline Physiological Silencing & $\begin{array}{l}\text { Occurs when physiological } \\
\text { impairments prevent the subject } \\
\text { from expressing themselves } \\
\text { through speech or compromise } \\
\text { this form of expression. }\end{array}$ & $\begin{array}{l}\text { Presbyphonia, wear of the vocal } \\
\text { cords, sequelae of stroke, such } \\
\text { as aphasia. }\end{array}$ \\
\hline Geospatial Silencing & $\begin{array}{l}\text { Occurs when facts or social } \\
\text { factors prevent the collective } \\
\text { expression of a group or } \\
\text { community }\end{array}$ & $\begin{array}{l}\text { Social isolation, confinement by } \\
\text { Pandemic }\end{array}$ \\
\hline Social Silencing & $\begin{array}{l}\text { are characterized by oppression } \\
\text { and omission of rights }\end{array}$ & $\begin{array}{l}\text { The elderly who are } \\
\text { institutionalized due to their } \\
\text { natural aging process or illness. }\end{array}$ \\
\hline Generational Silencing & $\begin{array}{l}\text { Occurs when a certain generation } \\
\text { imposes itself on another, } \\
\text { disqualifying for utterances }\end{array}$ & $\begin{array}{l}\text { Occurs when a certain generation } \\
\text { imposes itself on another, } \\
\text { disqualifying for utterances }\end{array}$ \\
\hline Labor Silencing & $\begin{array}{l}\text { This is always the result of labor } \\
\text { relations and power. }\end{array}$ & $\begin{array}{l}\text { Worker who is forced to take work } \\
\text { home, having his time kidnapped } \\
\text { by a power relationship }\end{array}$ \\
\hline
\end{tabular}




\begin{tabular}{|c|c|c|}
\hline Parental Silencing & $\begin{array}{l}\text { Associated with the overwhelming } \\
\text { imposition of parents on their } \\
\text { children. }\end{array}$ & $\begin{array}{l}\text { Elderly who have their lives } \\
\text { controlled by the will of their } \\
\text { children without considering their } \\
\text { autonomy. }\end{array}$ \\
\hline Individual Silencing & $\begin{array}{l}\text { It occurs through external } \\
\text { crossings or internal blocks, but } \\
\text { as a result of the relation of the } \\
\text { self with the self or with the } \\
\text { external. }\end{array}$ & $\begin{array}{l}\text { Due to lack of belief in oneself, or } \\
\text { in the future, the individual } \\
\text { becomes dull. }\end{array}$ \\
\hline Institucional Silencing & $\begin{array}{l}\text { Caused by the disciplinary nature } \\
\text { of any and all institutions }\end{array}$ & $\begin{array}{l}\text { The destitution of individual } \\
\text { singularity in favor of the collective }\end{array}$ \\
\hline Vertical Silencing & $\begin{array}{l}\text { It occurs when the individual } \\
\text { expresses himself in a longitudinal } \\
\text { way, between signs, words or } \\
\text { statements. }\end{array}$ & Speak lower \\
\hline Horizontal Silencing & $\begin{array}{l}\text { Its occurrence affects the } \\
\text { distance between one word and } \\
\text { another; it can be measured in } \\
\text { time, in fractions of seconds or } \\
\text { minutes. }\end{array}$ & Speak with more pauses \\
\hline Structural Silencing & $\begin{array}{l}\text { Due to poor income distribution or } \\
\text { lack of effectiveness of public } \\
\text { policies... }\end{array}$ & $\begin{array}{l}\text { Deficient supply of highly complex } \\
\text { care equipment for the elderly }\end{array}$ \\
\hline $\begin{array}{l}\text { Institucional Silencing } \\
\text { (general) }\end{array}$ & $\begin{array}{l}\text { Resulting from abusive actions or } \\
\text { violation of rights in public or } \\
\text { private institutions }\end{array}$ & $\begin{array}{l}\text { Absence of accessibility, } \\
\text { disrespecting the frailty condition } \\
\text { of the elderly }\end{array}$ \\
\hline
\end{tabular}

Source: MAXIMO PELIS (2020)

These forms of silencing exposed in the table above trigger silence, which is the manifestation of the impediment of saying. The consequence of the continued action of silencing something.

It can be identified in docile bodies or long pauses, in the absence of sounds or apathy of gestures. It is manifested by the meaning it carries, and as in the enunciation theory, identifying the actors (me, you and him), the time and the condition of production is decisive for understanding the meaning of silence. Silence can manifest itself in several ways (4).

Silence is the object of study in several areas, including Music, Philosophy, and Linguistics. Professor and technical director of the Harvard Acoustics and Electronics Laboratory, Leo L. Beranek, created the world's first anechoic chamber. In anechoic chambers, the "sound level, from a spherically irradiated source, decreases $6 \mathrm{db}$ every double the distance from the source" in an absorption coefficient that covers all angles of incidence, absorbing 99\% of ambient noise and its frequencies. Years later, John Cage, a poetmusician and multidisciplinary musician, upon learning of Beranek's invention, went to Harvard University's anechoic chamber to experience the absence of sounds. However, inside the anechoic chamber he heard two sounds, one high and the other low pitched. When asked, the responsible engineer replied about these sounds that "the loudest was the sound of your nervous system working. And the bass was the sound of your blood circulation" (9). Since then, Cage, who believed that there was absolute silence, found that "there is no silence that is not pregnant with sounds"
(10), as there will always be a sound, whether intentional or not.

To support his reflections, Cage appropriated the Zen philosophy, for which silence is the verb itself, so silence is body, silence is gesture, as quoted by HELLER. Anchored in the same precepts, Martin Heidegger, German philosopher, affirmed that, "nothing does not remain indeterminate opposite to the entity, but it reveals itself as belonging to the entity" (11) and ends up recognizing the linguistic function of silence when saying that "the language is found everywhere "and that" We speak continuously. We speak even when we don't let a word sound" (11); so if language is present in silence, silence is language.

For Linguistics, language is a complex communication system, and spoken language is "undoubtedly determined, essential part of it" (12). To Saussure, each sign has its internal value, meaning in itself. This is one of the main concepts presented by the linguist when comparing the linguistic system to a game of chess. In the "linguistic value", each piece of a board is equivalent to a sign. The value of a piece is not equivalent to the material of which it is made, but in the systematic relationship with the other pieces. Thus, language is form and not substance (12). In the analogy used by Saussure, a chess piece does not make it what it is by the substance of which it is made, but by the relationships it will have with other pieces. Therefore, the chess game takes place because of the rules and relationships (function in the system), and not the pieces as an object. 
Saussure stipulates a value for each sign, based on its signifier and its meaning, and Cage specifies a value for silence and says that the way to measure this value is by its duration (13). Heidegger, the philosopher, also explained silence (emptiness) with an analogy: using a jar, he elucidated that as a container, the jar has side and bottom, but it is not the side and bottom, and that the jar appears to be empty it is filled with air and everything that makes up air. If wine were poured into the jar, the air inside would be displaced and replaced by the liquid. So filling the wine jar would mean exchanging one content for another (14).

We conclude that silence is made up of countless possibilities of meanings and, although it is not represented by a sign, it is not empty, and can be presented in the following way proposed by MAXIMO PELIS, SAMPAIO\& OLIVEIRA (13):

\section{A Representação Gráfica do Silêncio The Graphic Representation of Silence}

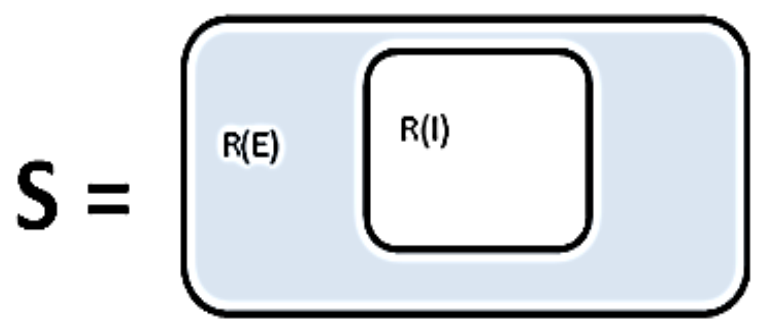

Figure 1: The Graphic Representation of Silence

When using the anechoic camera as a parameter, in the representation above, $R$ (E) refers to all noise external to the individual as the sounds of nature and the sounds produced by man; and R (I) represents all noise that is inside the individual, coming from inside (heartbeat, blood flow, peristaltic movements, neural system, etc.); and $S$ is silence (13).

When Beranek reduced R (E) by $99 \%, R$ (I) was revealed. $R(I)$ stands out whenever $R(E)$ tends to zero.

\section{(MAXIMO PELIS, SAMPAIO \& OLIVEIRA (2020)}

$E S$ is identified when the balance between $R(E)$ and $R$ (I) occurs. When one overlaps the other, the peak effect in this process can be disturbing, but when there is a supposed harmony between the two factors, this neutrality is what we call silence. According to the representation proposed by MAXIMO PELIS, SAMPAIO\& OLIVEIRA (13) and presented below:

\section{Equation of Silence}

- $S \equiv R(E)+R(I)$

- Srepresents the value of silence

- $\quad R(E)$ represents the sum of noise extemal to the body

- $R(I)$ the sum of the intemol noise within the body.

- $R(E)$ and $R(L)$ are measured in Megahertz (MHz) and defined by Equations (2) and (3):

- $R(E)=\sum_{-1} x_{i} i=(0+1+2+\cdots+n)$,

- $R(l)=\sum_{i=1}^{j} y_{i}^{i}=(1+2+\cdots+j)$,

- $\quad R(E)$ is the sum of the noises outside the being, which is in the environment, like the sounds of nature and those produced by man.

- $\quad R(I)$ is the sum of the noises that are inside the individual, coming from inside, for example: heartbeat, blood flow, peristalic movements, neural system, among others . 
Just as acoustic silence (S) is always different from zero, so is linguistic silence, a relevant object of study in this research. In permeating the signs or even in their absence, there is a saying or an unsaid thing that is imbued with meaning. Eni Pulcinelli Orlandi, a salient Brazilian linguist of today, in her work entitled "As Forms of Silence - in the movement of the senses" states that "in the beginning it is silence. The language comes later" (6). The senses are based on silence, and silence, in turn, also supports language. Imbued with possibilities, grounding meanings where there is "an unsaid" or "not saying", silence makes it possible. Silence is not speech because it is, in fact, part of language, in the field of semiology, and, using Saussure's linguistic value theory analogy, we find that its value is different from zero (4).

The equivalence between acoustic silence and silence as language allows the understanding that silence can be measured by time and that each manifestation will have a specific value and a singularity. Silence, in the language of the elderly affected by institutionalization, makes sense. To understand silence as a structuring of meaning, it is necessary to consider linguistic and semiotic cues, such as body movements, looking, smiling, gesturing, intonation, and especially the context of its production.

\section{ili. Methodology}

The research developed had a transversal, nonexperimental characteristic; it was based on the precepts of Discursive Neurolinguistics, a frontier discipline of linguistics. Qualitative in terms of data collection, the observation and analysis of the alternative meaning systems of five institutionalized older adults took place at Abrigo Nosso Lar, Long-Term Institution, in Vitória da Conquista. For data validation, a control group of five non-institutionalized older adults was created, of which two gave up for personal reasons. After signing and consenting by an Informed Consent Term and approval by the Ethics Committee (CEP: 3.050.076), the research data were obtained, through audiovisual resources, from transcription and direct observation in the meaning of non-verbal processes manifested. The data-found methodology, which enables the theorization of each data in a dynamic way "through the dialogical interaction between researcher and subject" (1), was applied, following the care model of the Aphasic Living Center of the State University of Campinas and the orientation of the Living Space Between Aphasics and Non-Aphasics (ECOA), from the State University of Southwest Bahia, coordinated by Professor Ph.D. Nirvana Ferraz Santos Sampaio who considers that silence can be justified as a point of intersection between aphasics and non-aphasics. In these environments, researchers, therapists, family members and friends are inserted in an interaction mediated by verbal and non-verbal language, as well as by their relationship with non-verbal systems (15). This article will present data regarding four institutionalized elderly persons.

\section{Data And Analysis: Silence And LisTENING}

The following will present some enunciativediscursive situations in which there is a dialogue between PSMP, a researcher, with four older adults accompanied during the research, identified with the following pseudonyms: Maria, Ofélia, Valdo and Iva and the context of the institutionalized condition of these elders, let's see:

a) Case 1

Angelina asked Sister Maria for a place at the institution, as she felt sick, unable to take care of Maria and another disabled sister, totally dependent. The three elderly sisters, single, with no other relatives, received help from friends in the church. Maria was talkative when she was institutionalized. She told stories, was helpful, led the chair of other older adults, and offered help, always with a lot of autonomy. When she arrived at the institution, Maria felt at ease and belonged to that place, to the point of washing her underwear in the spring water, in the central part of the garden and spreading them on the sideboards. Her attitudes were resisted by the institutional demands that delimited their individual space. Institutional silencing affected her and as an initial resource she showed her sister her indignation. Her belongings were selected for institutionalization. The rest remained at her home. She missed what she left there. She missed her clothes that she took with her and that she assumed they were stolen when she couldn't find them. 
Table 2: Inadequacy, Disengagement

\begin{tabular}{|c|c|l|c|c|}
\hline Turn & Interlocutor & \multicolumn{1}{|c|}{ Statements } & $\begin{array}{c}\text { Verbal } \\
\text { Production } \\
\text { Observations }\end{array}$ & $\begin{array}{c}\text { Non-Verbal } \\
\text { Production } \\
\text { Observations }\end{array}$ \\
\hline 1 & Maria & Come here.. & $\begin{array}{c}\text { Cup your hand as } \\
\text { if telling a secret }\end{array}$ \\
\hline 2 & PSMP & What's the matter with you? & & Complains \\
\hline 3 & Maria & My skirt ... They took my things. & $\begin{array}{c}\text { Referring to } \\
\text { clothes at home }\end{array}$ & \\
\hline 4 & Maria & Me with each one good, girl. & & Smiled \\
\hline 5 & Maria & Call Angelina, ask to bring here ... & & \\
\hline 6 & Maria & $\begin{array}{l}\text { You are so good ... if I had money I } \\
\text { would give it to you. }\end{array}$ & & \\
\hline
\end{tabular}

Fonte: MAXIMO PELIS (4)

Until that moment, Maria's statements and her ability to articulate words were preserved. But Sister Angelina, in fragile health, feared that Maria would ask to be taken home. And she kept away, no longer visiting her. At that moment, Maria's behavior began to change: "I thought she was much more agitated. Much more agitated "says and reinforces the institution's social worker. But, with the continuity of that situation, the permanence of the impediments, the unheard sayings, the agitation gave way to apathy. According to the Nurse's report, "she stayed with her bags packed on the bed for a while, thinking she was leaving. He said that "I am leaving today" [...] Today he no longer puts it [...] Today he no longer speaks and is isolating himself. You no longer see Maria talking; she used to be very talkative. "What the Institution's Nurse confirms is that Maria's silence was verbal because she "no longer speaks" and non-verbal when changing her behavior "in isolation". Silence produced silence full of meaning (indignation, revolt, sadness, longing) to account for its incompleteness.

\section{b) Case 2}

Ofélia was institutionalized by Sister Odete, who, for health reasons, could not provide assistance to her sister who lived alone, perceiving institutionalization as a support solution for Ofélia. Ofélia loves to sing, tell stories, always excited and smiling. However, the loss of work, the lack of coexistence, and the loss of autonomy due to senility, led her to end up at home. According to Odete her sister Ofélia "was very talkative" she gets a little quieter, right? Depending on her age, she changed that a little bit, and she liked to walk a lot and then the desire to walk started decreasing and she became more home ... But even so she sometimes says: Look, I wanted to go to that party and dance ..."

At the institution, the silencing process was not interrupted. The lack of interactivity among the elderly, which, like Ofélia, has reduced functionality, perpetuates this process causing sequelae. As a psych pedagogue, Odete speaks properly about the effect of the lack of interaction with Ophelia's language, as described in MAXIMO PELIS (2020):

"Look, it is because I think so: the elderly are like that, they are much paraded, silent, without talking to each other. [...] There should be an interaction between the elderly and the other, so that they can talk, because they may even lose their voice ... Do you understand? That's exactly what I feel ... In the case of Ofélia, I'm feeling that she is talking less ... So this elderly person's interaction with the other is missing ... I think I should change a little". (Odete)

For Bakhtin (5) it is in the interactive situation, in social relations, that statements are produced and apprehended. Therefore, the lack of interaction imprisons the individual at the limit of his own production and it is known that the elderly individual, senescent or senile, has reduced individual production due to limitations of abilities and skills, as an effect of aging. For Ofélia, social and institutional silencing narrowed the lines that delimit the individual's production, and can lead her to "even lose her voice" the materiality of silence.

c) Case 3

Valdo lived alone. After becoming a wheelchair user, he was advised to institutionalize himself. He was aware that his current physical condition would make it impossible for him to return to his old home. 
Table 3: Silence as Recognition

\begin{tabular}{|c|c|c|c|c|c|}
\hline Turn & Interlocutor & Time Code & Statements & $\begin{array}{c}\text { Verbal } \\
\text { Production } \\
\text { Observations }\end{array}$ & $\begin{array}{l}\text { Non-Verbal } \\
\text { Production } \\
\text { Observations }\end{array}$ \\
\hline 1 & PSMP & [00:00:00.00] & $\begin{array}{l}\text { Do you know what date it is } \\
\text { today? }\end{array}$ & & \\
\hline 2 & Valdo & [00:00:04.00] & Today is 5th. & & \\
\hline 3 & PSMP & [00:00:05.00] & Five of what month? & & \\
\hline 4 & Valdo & [00:00:07.00] & March Five & & \\
\hline 5 & PSMP & [00:00:10.00] & $\begin{array}{l}\text { Do You Know watch year we } \\
\text { are in? }\end{array}$ & & \\
\hline 6 & Valdo & [00:00:14.00] & 2009,2019 & & \\
\hline 7 & PSMP & [00:00:20.00] & $\begin{array}{l}\text { What kind of institution are you } \\
\text { living in? }\end{array}$ & & \\
\hline 8 & Valdo & $\begin{array}{l}00: 00: 21.00] \\
{[00: 00: 28.00]}\end{array}$ & Nosso Lar. & & $\begin{array}{l}\text { Look up and } \\
\text { then look to the } \\
\text { side for } 6 \mathrm{~s} \\
\text { Looking at } \\
\text { PSMP }\end{array}$ \\
\hline 9 & PSMP & [00:00:33.00] & $\begin{array}{l}\text { Nosso Lar, It is what? A } \\
\text { hospital, a nursing home? }\end{array}$ & & \\
\hline 10 & Valdo & $\begin{array}{l}{[00: 00: 39.00]} \\
{[00: 00: 42.00]}\end{array}$ & $\begin{array}{l}\text { For me, I think it's a nursing } \\
\text { home ... Because a hospital ... } \\
\text { it's not "like" a hospital ... }\end{array}$ & & \\
\hline 11 & PSMP & $\begin{array}{l}{[00: 00: 57.00]} \\
{[00: 00: 59.00]}\end{array}$ & $\begin{array}{l}\text { The moment you came to stay, } \\
\text { what impacted you the most? } \\
\text { I know that you had already } \\
\text { made some visits before, but, } \\
\text { what impacted you the most? }\end{array}$ & & \\
\hline 12 & Valdo & [00:01:08.00] & For me to come? & & thoughtful \\
\hline 13 & PSMP & [00:01:10.00] & $\begin{array}{l}\text { When you came in it was very } \\
\text { tearful in the first days.... }\end{array}$ & $\begin{array}{l}\text { Rephrase the } \\
\text { question }\end{array}$ & \\
\hline 14 & Valdo & $\begin{array}{l}00: 01: 13.00] \\
\\
{[00: 01: 14.00]} \\
{[00: 01: 15.00]} \\
{[00: 01: 16.00]}\end{array}$ & $\begin{array}{l}\text { It was because there was a } \\
\text { song, then } \\
\text { I remembered the known..... } \\
\text {..... the lady of the house who } \\
\text { liked me a lot } \\
\ldots \text { They all... }\end{array}$ & & \\
\hline 15 & PSMP & [00:01:39.00] & $\begin{array}{l}\text { And in this beginning, in that } \\
\text { first week, how is your routine } \\
\text { inside here? }\end{array}$ & & \\
\hline 16 & Valdo & $\begin{array}{l}{[00: 01: 45.00]} \\
{[00: 01: 50.00]} \\
{[00: 01: 51.00]} \\
{[00: 01: 52.00]} \\
{[00: 01: 53.00]}\end{array}$ & $\begin{array}{l}\text { I'll take it as God wants } \\
\text { If he sees that I deserve one } \\
\text { day I come home... }\end{array}$ & & $\begin{array}{l}\text { (looks down) } \\
\text { Looks down on } \\
\text { chin }\end{array}$ \\
\hline 17 & PSMP & [00:01:54.00] & $\begin{array}{l}\text { Do you get hope to return } \\
\text { home? }\end{array}$ & & \\
\hline 18 & Valdo & {$[00: 01: 55.00]$} & I have, I have & & $\begin{array}{l}\text { (Keeps your } \\
\text { eyes down }\end{array}$ \\
\hline
\end{tabular}

Fonte: MAXIMO PELIS(4)

In turns 1 to 6 of the table above, Mr. Valdo's good time-space orientation is verified. In turns 7 and 8 , the delay in the response, as can be seen in the column with the time code, looking upwards and later to the side until the possibility of facing the researcher, recognizing and giving nominally the place that is now her home, gives silence a sense of place recognition and, at this moment, silence intervenes as part of the subject's relationship with the sayable (6). The real and sayable thing for Valdo is his new home, the ILPI Nosso Lar. It has representativeness for the subject, and several meanings. The possible meaning, for Valdo, who can 
sustain the temporality of a stay, is that this place is a hospital. In the elaboration of this statement, silence, which is not just pauses, allows the elimination of a meaning, that is, Valdo, in saying that that place is a hospital, for a moment, erases the fact of being permanently in this strange place - now your home (4). Silence, in turn 13, works like censorship, not being able to say that your reality is past. When asked if he hopes to return home, on turns 16 and 18, the silence between one and the other sentence is corroborated with body language, and imbued with a sense of discouragement, reveals the unspoken and contradicts the saying: I have, I have.

\section{d) Case 4}

Iva's family relationship was fragmented. His son was distant and his granddaughter was the one who gave him attention. However, the granddaughter took care of her mother-in-law when her father and Iva appeared in her life asking for shelter. The son decided to institutionalize the mother (or he did not object). He was distant, he remained distant. She visited Iva very little, and when her granddaughter came to spend the weekend at home, her absence was also common. The effect of family breakdown on institutionalization is one of sadness, loneliness, discomfort and anguish.

Table 4: Silence and the Death Wish

\begin{tabular}{|c|c|c|c|c|c|}
\hline Turn & Interlocutor & Time Code & Statements & $\begin{array}{l}\text { Verbal Production } \\
\text { Observations }\end{array}$ & $\begin{array}{l}\text { Non-Verbal } \\
\text { Production } \\
\text { Observations }\end{array}$ \\
\hline 1 & PMSP & {$[00: 01.07]$} & Are You sad? & & \\
\hline 2 & Iva & [00:02.17] & & $\begin{array}{l}\text { Open your eyes, } \\
\text { and close your eyes }\end{array}$ & $\begin{array}{c}\text { Shakes her } \\
\text { head meaning } \\
\text { Yes. }\end{array}$ \\
\hline 3 & PSMP & [00:02.32] & Let's do na activity? & & \\
\hline 4 & Iva & [00:02.41] & Not today... & & $\begin{array}{c}\text { Shakes her } \\
\text { head meaning } \\
\text { No }\end{array}$ \\
\hline 5 & Iva & [00:02.44] & On Tuesday? & $\begin{array}{c}\text { Open and close eyes } \\
\text { slowly }\end{array}$ & \\
\hline 6 & Iva & [00:02.49] & Not. & $\begin{array}{c}\text { Open and close eyes } \\
\text { slowly }\end{array}$ & \\
\hline 7 & PSMP & [00:02.52] & Why? & & \\
\hline 8 & Iva & [00:03.01] & $\begin{array}{l}\text { Because I'm going to } \\
\text { die, I don't die, I will. }\end{array}$ & $\begin{array}{c}\text { Lying on the couch, } \\
\text { covered and eyes } \\
\text { closed }\end{array}$ & \\
\hline
\end{tabular}

Fonte: MAXIMO PELIS (4)

In the table above, the researcher invites Iva to an activity. Iva was sad: her granddaughter and son had not appeared in days. The deep pain exhaled by his non-verbal language denotes a death wish (turns 2, 4 and 6). The feeling of death (turn 8) corresponds to abandonment, invisibility, insignificance. Amid the listening and intervention of PSMP: "Why", silence becomes the possibility for Iva to measure the pain that permeates her soul, and elaborate the equivalence of that pain, or liberation, to death.

\section{Conclusion}

This article, in attesting that institutionalization affects the language of the elderly, corroborates the hypothesis that the resignification of verbal language by non-verbal language is recurrent, and that silence, as a language, is part of an alternative system of possible meaning for institutionalized elderly (re) elaborate desires and meanings. When identifying the process that produces silence, from a table of silencing possibilities, it is also verified that the institutional environment is a collective environment that cancels the singularity and produces the awakening that is one of the many forms of silencing. As a product of the silencing process is silence. Silence is not the absence of sounds, it is the possibility of reframing because it is impregnated with meaning, and it is a reframing mechanism of value and possibilities. As a structuring of meaning, silence belongs to language and has value as such. In order to understand silence, the subject's history rescue is necessary and, through careful listening, it is possible, in the interlocution, to restructure meanings, recovering the necessary senses for resignification and maintenance of the subject's identity $(4,13)$. This work is relevant for professionals in the field of psychology, linguistics, and gerontology because it provokes the understanding of silencing and silence by professionals working in institutions, such as long-term institutions for the elderly who, in favor of the collective, incline to cancel the individual's uniqueness. 


\section{References Références Referencias}

1. COUDRY MI. Discursive neurolinguistics: aphasia as a translation. Study from Ling. 2008; v.6, n.2: 7-36.

2. IBGE 2014. IBGE Library

3. BERGER L, MAILLOUX-POIRIER D. Elderly People: A Global Approach - Nursing Process by Needs. Lisbon; 1995,

4. MAXIMO PELIS S. Silence: Language in a LongTerm Institution for the Elderly. Vitória da Conquista, BA: Linguistics Post-ProductionProgram, UESB-BA; 2020. p. 138.

5. BAKHTIN M. Marxism and Philosophy of Language. 13a. Trad. M. Lahudand Yara F. Vieira, editor. São Paulo: Hucites;

6. Orlandi E. The forms of silence. The forms of silence. 1992. p. 39-59.

7. ROCHA, IMSNC. Memory, Asylum Space and Representations: a study on elderly people's narratives. UESB - State University of Southwest Bahia; 2010.

8. BERNARDO KF. On Language and Interaction in a Long-Term Care Facility for the Elderly.Vitória da Conquista, BA: Linguistics Post-ProductionProgram, UESB-BA; 2015.

9. CAGE J. Silence, Lectures and Writings. Wesley University Press Middlet [Internet]. Available from: https://archive.org/details/silencelecturesw1961cag e/page

10. HELLER AA. John Cage and the poetics of silence. Repository University Fed St Catarina (Doctoral Thesis in Lit [Internet]. 2008; Available from: http://repositorio.ufsc.br/xmlui/handle/123456789/91 918

11. HEIDEGGER M. On The Way of Language. 1982.

12. SAUSSURE F. General Linguistics Course. 28a. São Paulo: Editora Culttrix;

13. MAXIMO PELIS S, SAMPAIO, Nirvana Ferraz Santos, OLIVEIRA JCM. Relevant aspects of silence for the construction of meaning in data from an elderly woman living in a long-term institution. Rev Let Raras [Internet]. 2020; v.9, n. 1. Available from: http://revistas.ufcg.edu.br/ch/index.php/RLR/article/ view/1569

14. LIMA J dos S. the Heidegger Lima thing [Internet]. Natal, RN: Revista Saberes, Vol. 1, n. 4, p. 96-102; Availablefrom: http://www.cchla.ufrn.br/saberes

15. SAMPAIO NFS. A sociolinguistic approach to aphasia: the Aphasic Community Center (UNICAMP) as a speaking community. Nirvana Ferraz Santos Sampaio. - Campinas, SP: [s.n.], 2006. (DoctoralThesis) 